\title{
Microbial and Physical Chemical Indicators of Groundwater Contamination in Kenya: A Case Study of Kisumu Aquifer System, Kenya
}

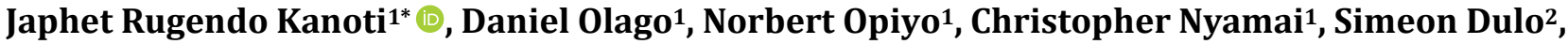 Richard Ayah ${ }^{3}$}

${ }^{1}$ Department of Geology, University of Nairobi, Nairobi, Kenya

${ }^{2}$ Department of Civil and Construction Engineering, University of Nairobi, Nairobi, Kenya

${ }^{3}$ School of Public Health, University of Nairobi, Nairobi, Kenya

Email: *kanoti2002@yahoo.com

How to cite this paper: Kanoti, J.R., Olago, D., Opiyo, N., Nyamai, C., Dulo, S. and Ayah, R. (2019) Microbial and Physical Chemical Indicators of Groundwater Contamination in Kenya: A Case Study of Kisumu Aquifer System, Kenya. Journal of Water Resource and Protection, 11, 404-418. https://doi.org/10.4236/jwarp.2019.114024

Received: March 27, 2019

Accepted: April 23, 2019

Published: April 26, 2019

Copyright $\odot 2019$ by author(s) and Scientific Research Publishing Inc. This work is licensed under the Creative Commons Attribution International License (CC BY 4.0).

http://creativecommons.org/licenses/by/4.0/

(c) $\underset{\mathrm{EY}}{\mathrm{C}}$ Open Access

\begin{abstract}
Safe water of adequate quantity, and dignified sanitation, is vital for the sustenance of a healthy and productive human population. In the recognition of this, the United Nations formulated the Sustainable Development Goal No. 6 to ensure access to safe water and sanitation by all by 2030. Actualization of this Goal requires information on the existing status of water resources and sanitation levels. Knowledge on contamination of groundwater is essential to prevent risks to human health. The objective of this study was to determine groundwater contamination in Kisumu, Kenya. A total of 275 water samples were collected from 22 sites within the informal settlements between December 2016 and December 2017. The samples were analysed for bacterial contamination and physical chemical quality. Thermal tolerant coliform bacteria enumeration was used as a proxy to bacteria contamination, and the $\mathrm{pH}$, turbidity, dissolved oxygen, conductivity, salinity and temperature were used as physical chemical indicators of contamination. The results indicate that groundwater in Kisumu hosed coliform bacteria and therefore didn't comply with contamination limits for domestic water proposed by WHO and local KEBS standards. The results further indicated that the levels of bacteriological contamination vary with water type, shallow well having the highest bacterial loads. The study concluded that there were potential risks to human health due to high content of coliform bacteria. The study attributed the contribution to pit latrines that were present in virtually all compounds. The pit latrines are located close to the water points. The study recommended the definition of minimum distance between the pit latrines and shallow wells to minimize contamination. The low income dwellers should be educated on sim-
\end{abstract}


ple ways of treating drinking water contaminated by microbial to minimize enteric infections.

\section{Keywords}

Groundwater Pollution, Thermal Tolerant Coliforms, Physical Chemical Quality, Kisumu, Kenya

\section{Introduction}

Availability of water is one of the basic human needs that must be met in adequate quantity and quality consistent with minimum health standards [1]. Globally, groundwater and surface water are the main sources of water for human consumption [2]. However, rapid urbanization and lack of adequate disposal mechanisms of human waste has led to contamination of these water resources [3]. Since surface water is more susceptible to contamination from anthropogenic activities, attention in most developing countries is shifting to the development of groundwater for potable water supplies [4] [5]. However, the occurrence and distribution of groundwater is complicated by complex hydrogeological settings and conditions [6]. The composition of precipitation, coupled with anthropogenic activities and geological processes within an aquifer determine the quality of groundwater [7]. Groundwater is also continually being threatened with contamination by human waste from toilets [8], which can reach groundwater through the aquifer pathways and also through man-induced pathways [9]. Studies conducted in Sub-Saharan Africa have found that groundwater abstracted from water points located near pit latrines can be contaminated with microorganisms, and that shallow wells are more susceptible than deeper boreholes [10] [11] [12] [13]. Contamination is more pronounced when the latrines are sited at a higher altitude than the wells [14]. It's however, worth noting that on-site sanitation does not inevitably cause groundwater contamination; the authors found that such contamination is also influenced by numerous complex factors that include the underground conditions contributed by various soil/rock formations. They also noted that the most critical distinction below the surface is between the saturated and the unsaturated zone.

There is therefore need for planning to utilize the sub-surface for water supplies and sanitation [15] to reduce the incidences and prevalence of diseases caused by pathogenic microorganisms [16]. To limit exposure of groundwater sources to biological contamination, a horizontal distance of $30 \mathrm{~m}$ between pit latrines and water sources has been proposed by some researchers.

The natural aquifer contamination pathways are defined by the hydrogeological environment, and the factors involved include soil/rock characteristics such as porosity, permeability, transmissivity and faults. Man-induced pathways are created during the design phase of the water point, during the construction and development of groundwater supply, and during the production stage [17] [18] 
[19]. Contamination of water is normally confirmed by the presence of bacteria that indicate faecal contamination by coliforms [20] [21] [22]. Indicator bacteria are, however, of limited use in predicting the presence of protozoa and viruses; waterborne disease outbreaks have occurred where coliform results are negative and this could be traced to viruses or protozoa [22]. Further, the probability of becoming infected after consuming contaminated water depends on the concentration levels and persistence of the pathogen in the groundwater. Infection also depends on the infectious dose required to initiate a disease, with the median infectious dose for bacteria being typically more than 10,000 pathogens [17].

Groundwater is the main alternative source of water in both rural and urban areas in Kenya. These groundwater supplies are obtained from hand dug shallow wells, springs and boreholes. Boreholes have been drilled within the Kisumu aquifer by government departments, corporations, private firms and individuals since 1939 to present. The early boreholes were used for domestic, irrigation and industrial purposes because piped water from Lake Victoria had not been commissioned. Shallow wells and boreholes continue to be the most reliable sources of water in Kisumu [19]. The water quality from these sources is comparatively better than those from surface water sources. But the use of the sub-surface as a repository of human waste due to low sewer connection in peri-urban areas and increasing human population has challenges, since groundwater may host a wide range of pathogens. These include viruses, bacteria, protozoa and helminths that render the population susceptible to various diseases [18]. Most guidelines and standards for drinking water recommends an absence of pathogens since the susceptibility to diseases is not uniform but depend on the person's immunity status, nutritional status, known seasonality of human infections and the characteristics of the aquifer system [9].

The main objective of this study was to determine faecal contamination and physic-chemical composition of groundwater in the study area. The study explored the microbial water quality and physical-chemical characteristics of groundwater in Kisumu in order to better understand suitability for human use. Specifically, the study used the presence of thermal tolerant coliform bacteria as proxies for bacterial contamination and related this to physical chemical properties of water [23]. This template, created in MS Word 2007, provides authors with most of the formatting specifications needed for preparing electronic versions of their papers. All standard paper components have been specified for three reasons: 1) ease of use when formatting individual papers, 2) automatic compliance to electronic requirements that facilitate the concurrent or later production of electronic products, and 3) conformity of style throughout a journal paper. Margins, column widths, line spacing, and type styles are built-in; examples of the type styles are provided throughout this document and are identified in italic type, within parentheses, following the example. Some components, such as multi-leveled equations, graphics, and tables are not prescribed, although the various table text styles are provided. The formatter will need to create these components, incorporating the applicable criteria that follow. 


\section{Background Information}

\subsection{The Study Area}

The study area is located in Kisumu, Kenya, on the shores of Lake Victoria, Figure 1. Kisumu City is the third largest city in Kenya with a population of over 1 million inhabitants. The formal and planned settlements in Kisumu are supplied with water and sewerage services by the utility company. However, these services are limited or do not exist in the informal settlements. Residents in these settlements therefore revert to digging shallow wells for water access and pit latrines for sanitation services.

\subsection{Climate}

The climate is the inland equatorial type modified by the effects of altitude, relief and the influence of Lake Victoria. The Lake influence has a slight cooling effect on temperature in the area [24] Temperatures in the lowlands range from a mean minimum of $17^{\circ} \mathrm{C}$ to a mean maximum of about $30^{\circ} \mathrm{C}$. In the higher altitudes, the mean minimum and maximum temperatures vary between $14^{\circ} \mathrm{C}$ and $25^{\circ} \mathrm{C}$, respectively. Two relatively dry (June to September and December to February) and two wet (March to May and September to November) seasons can be distinguished. However, the lengths of the seasons constantly change due to climate variability [25]. The mean annual rainfall varies with altitude and proximity to the highlands; it ranges between $1000 \mathrm{~mm}$ and $1800 \mathrm{~mm}$, with higher rainfall in the highlands and lower rainfall in the lowlands.

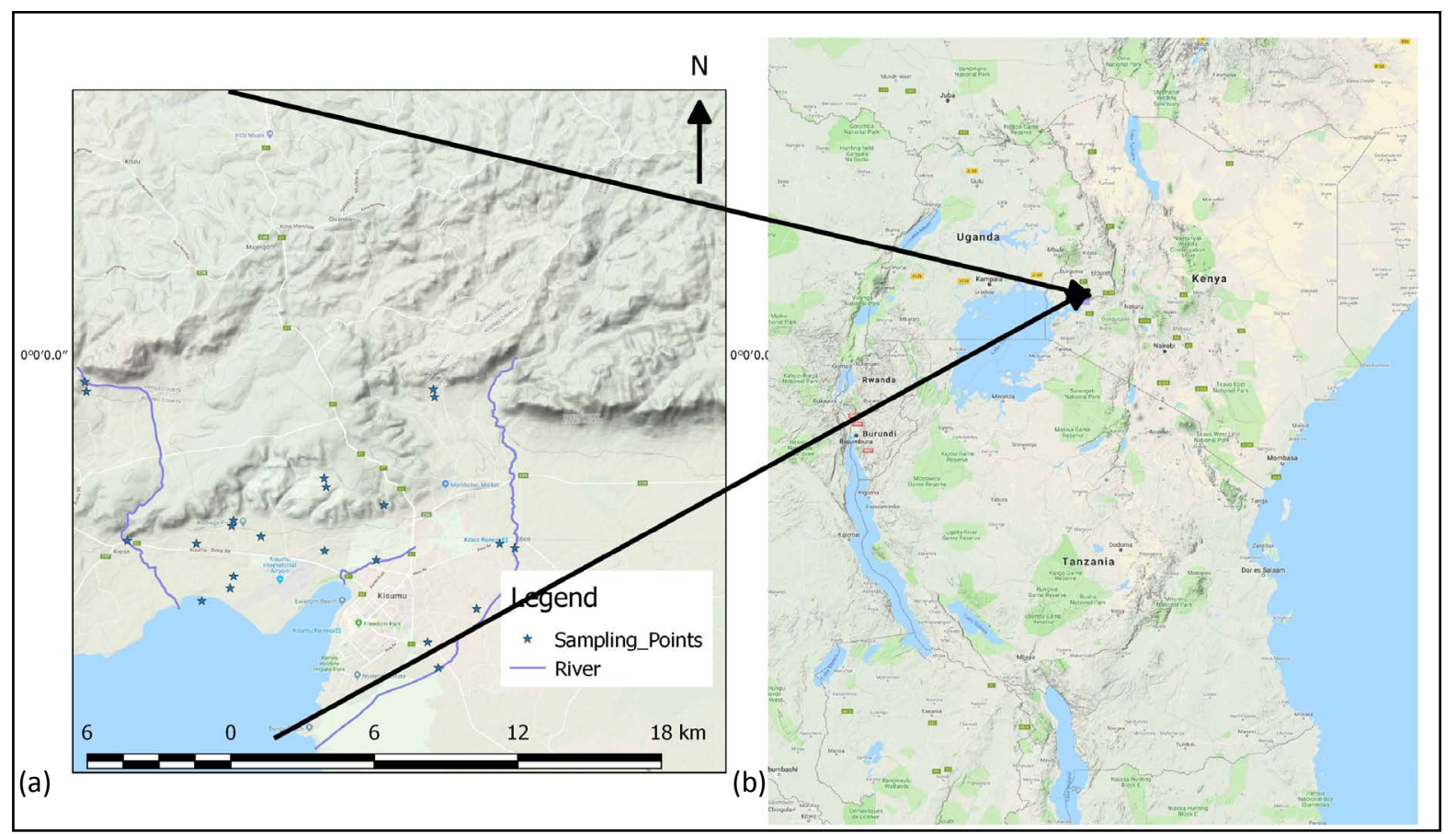

Figure 1. Location map of the study area. Note the location of the water sampling points north of the Lake. The study area lies between the Nandi escarpment and Lake Victoria shores. Map (a) shows the sampling points and (b) location of Kenya. 


\subsection{Geology and Hydrogeology of the Study Area}

The rocks in the study area fall into four main groups based on their geological age. These are the Precambrian (Archean) rocks that belong to the Nyanzian System, Tertiary volcanic rocks associated with the Kavirondo Rifting, Pleistocene and Recent deposits. It is evident that between the early Precambrian and Tertiary, there is a major geological hiatus, a period of no major geological activity [26].

The physiography and geology of Kisumu controls the recharge, movement and discharge of groundwater. Kisumu Aquifer System consists of unconsolidated and semi-consolidated inter-granular material with moderate to high flow groundwater characteristics in the central transect. The unconsolidated phonolitic boulders intercalated with murram form the main aquifer units but where the clay content is high, the yields and water quality is low. The western transect, defined by River Kisian, is dominated by granitic rocks and groundwater yield is low. Nyamasaria River forms the eastern transect and is located within recent sediments. Groundwater occurrence is good due to recharge from the Nandi hills to the north. Recharge occurs both by direct rainfall infiltration and through leakage of surface water along the main geological faults and weathered lava flow surfaces and contacts. We consider that the gradational contacts of phonolititic and andesitic rocks along the uplands of the western and the middle transects are the main recharge sites and the regolith on the weathered granites along the Nandi escarpment to be the recharge zones for the eastern and also western transects, respectively. The hydrologic setting is shown in Table 1.

Kisumu city has several informal settlements that lack access to reliable piped water and sewerage system. These settlements include Bandani, Manyatta, Nyalenda, Otonglo and Obunga, Figure 2. These settlement rely on alternative sources including shallow well, communal springs and water vendors. The informal settlements abut high-income neighbourhoods like Milimani. These estates are served by sewer system and supplied with reliable water. Though there are water shortages in these neighbourhoods, most houses have high capacity elevated storage tanks that take them through during the water shortage period.

Some planned settlements are slowly being converted into congested estates through unplanned infill development [19]. Our survey confirmed that most dwellings and communal water points in these settlements are served with piped water. However, most of the times these taps are dry and/or supply is insufficient. Therefore, the residents of these informal settlements revert to alternative sources that include communal springs, shallow wells and boreholes.

\section{Materials and Methods Background Information}

\subsection{In-Situ Measurement of Physical Chemical Parameters}

Twenty two water points, comprising rivers (4 sampling points), lake (1 sampling point), springs (5 sampling points), shallow wells (8 sampling points) and boreholes (4 sampling points) were selected for monthly in situ measurement of 
Table 1. Table type styles Hydrogeological setting with reference to the three transects (Figure 2).

\begin{tabular}{|c|c|c|c|c|}
\hline \multirow{2}{*}{$\begin{array}{l}\text { Water } \\
\text { Source }\end{array}$} & \multirow{2}{*}{$\begin{array}{c}\text { Sampling } \\
\text { points }\end{array}$} & \multicolumn{3}{|c|}{ Geology at Sampling Site } \\
\hline & & Transect 1 (Western Transect) & Transect 2 (Central Transect) & Transect 3 (Eastern Transect) \\
\hline River & 4 & $\begin{array}{l}\text { River Kisian originate from the } \\
\text { Maragoli Hills and contribute along } \\
\text { its length to the groundwater system. } \\
\text { The hills composed of granite and } \\
\text { lowlands recent granitic soils }\end{array}$ & $\begin{array}{l}\text { No river along this transect but all springs } \\
\text { located here convert into small streams } \\
\text { during heavy rain. Andesite, phonolite, } \\
\text { murrum, black cotton soils and grit forms } \\
\text { the cross-section from the hills to Lake } \\
\text { Victoria (no river samples) }\end{array}$ & $\begin{array}{l}\text { River Kibos/Nyamasaria originate from } \\
\text { the Nandi Hills and contribute to } \\
\text { groundwater balance on the eastern } \\
\text { transect. Nandi hills dominated by } \\
\text { granite, lowlands by black cotton soils } \\
\text { and the Lake shore by grit }\end{array}$ \\
\hline Spring & 5 & No spring along this transect. & $\begin{array}{l}\text { Four sampling springs and all are } \\
\text { located on unconsolidated phonolitic } \\
\text { rocks and murram. ( } 48 \text { samples) }\end{array}$ & $\begin{array}{l}\text { A single spring located at the contact } \\
\text { between grit and phonolite in Manyatta. } \\
\text { Small springs sprout during rains. }\end{array}$ \\
\hline $\begin{array}{c}\text { Shallow } \\
\text { Well }\end{array}$ & 8 & $\begin{array}{l}\text { Shallow wells are located along this } \\
\text { transect on phonolitic boulders and } \\
\text { murram. }\end{array}$ & $\begin{array}{l}\text { Wells along this transect are very } \\
\text { shallow, less than a meter especially in } \\
\text { Obunga. Murram (lateritic soil) is the } \\
\text { main formation. (12 samples) }\end{array}$ & $\begin{array}{l}\text { Recent black cotton soils dominate the } \\
\text { Kano plains. High clay content within } \\
\text { the Kano plains lenders shallow well } \\
\text { construction difficult. However, a few } \\
\text { wells are located on the upper reaches } \\
\text { of this transect in Kibos and Kajulu. }\end{array}$ \\
\hline Borehole & 4 & $\begin{array}{l}\text { None on this transect. Shallow depths } \\
\text { to the solid basement rock renders } \\
\text { drilling not to be cost effective. }\end{array}$ & $\begin{array}{l}\text { Very productive boreholes between the } \\
\text { contacts of the andesites and phonolite. } \\
\text { (12 samples) }\end{array}$ & $\begin{array}{l}\text { Very productive boreholes with the } \\
\text { Kano plains where the drilling } \\
\text { penetrate through the black cotton soil. }\end{array}$ \\
\hline Lake & 1 & $\begin{array}{l}\text { Shoreline geology is characterised by } \\
\text { clay and grit }\end{array}$ & $\begin{array}{l}\text { Lake Shoreline geology composed of } \\
\text { grit (No sample) }\end{array}$ & Grits on the Lake shoreline. \\
\hline
\end{tabular}

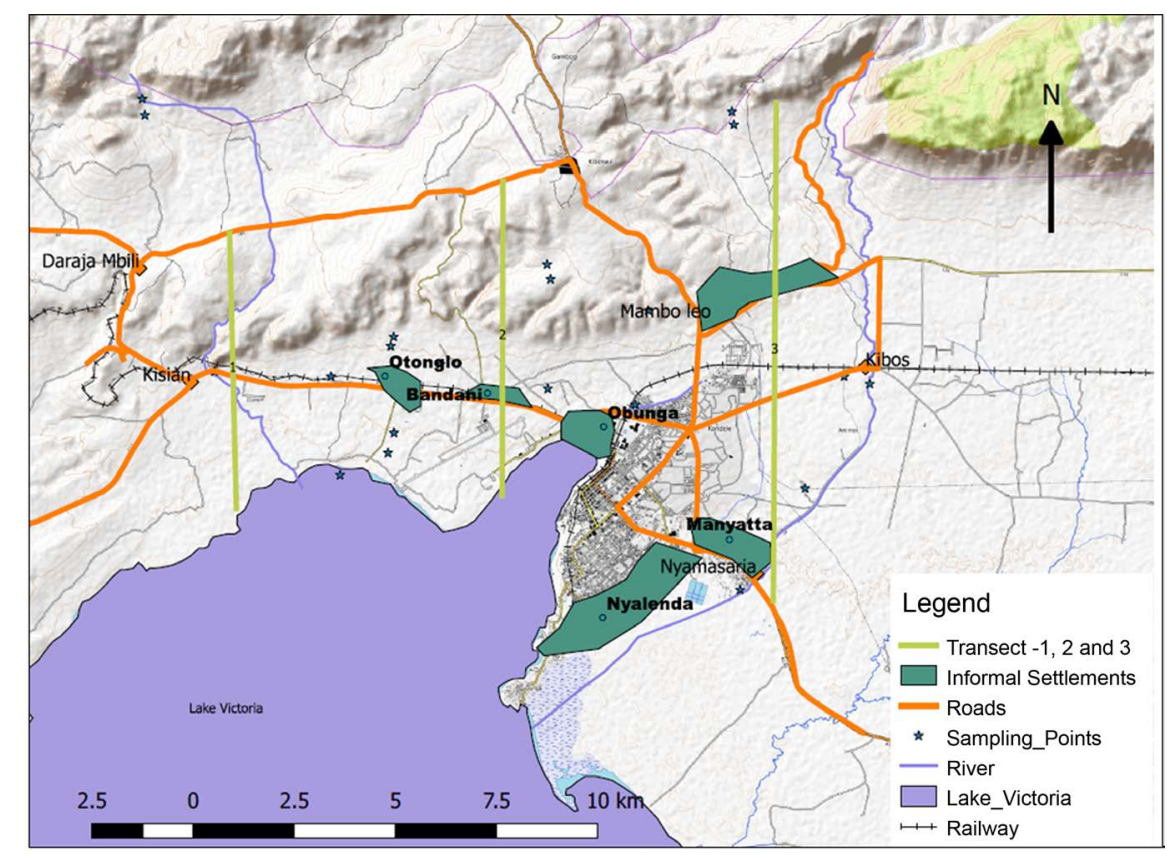

Figure 2. Relief map of Kisumu showing the peri-urban estates of Otonglo, Bandani, Obunga, Mambo leo, Manyatta and Nyalenda The hills to the north are the main recharge areas.

physical chemical parameters $(\mathrm{pH}$, temperature, conductivity, salinity, dissolved oxygen, and turbidity) for the period December 2016 to December 2017, using a portable Quanta hydrolab kit. According to EPA (2009), a minimum sample size 
of 8 to 10 wells is recommended when studying groundwater [27]. The selection of sampling points was based on three north-south trending transects, each delineated by taking into account the recharge and discharge zones, the west to east and north to south variations in geology within the study area, as well as altitude variation (high to low in each of the N-S oriented transects), Figure 2. The sampling sites locations and altitudes were recorded using a Global Positioning System (GPS). The water level in shallow wells were monitored using an In-Situ Inc. rugged level tape 100. Water levels in the deep boreholes were not measured because they lacked airlines.

\subsection{Analysis of Thermal Tolerant Bacteria in Groundwater}

In order to investigate the occurrence of thermal tolerant bacteria (TTC) in groundwater, water samples were collected aseptically from the 22 water points mentioned above, using approved sampling methods [28]. They were immediately stored in a cooler box at $4^{\circ} \mathrm{C}$ and incubated in a portable Wagtec bacteriological kit within four hours. This study used the membrane filtration technique [29]. The method involves filtration of water samples through a sterile filter with a pore size diameter of 0.45 microns. Bacteria cannot pass through this pore diameter and are therefore trapped in the filter. The filter with trapped bacteria was then placed on an absorbent pad with culture medium and incubated. Typical colonies on the filter were enumerated after incubation for 18 hours at $44^{\circ} \mathrm{C} \pm 1^{\circ} \mathrm{C}$. During the incubation period, the thermal tolerant coliforms multiplied rapidly and formed colonies that were visible to the naked eye as yellow coloured clumps against the pinkish background of the growth media. These yellow colonies were enumerated, and the results were expressed as colony forming units (CFU) per $100 \mathrm{ml}$ of water (CFU/100 ml).

This method has limitations that include long incubation periods and poor detection of slow growing microorganisms [30]. Only about $0.1 \%-15 \%$ of the total bacterial population in a sample grows and can be enumerated by methods based on culture media. The other concern about membrane filtration method is its inability to recover stressed or injured coliforms. However, this was overcome in this study by resuscitating the specimen for two to three hours in the incubator at $35^{\circ} \mathrm{C}$ subsequent to incubation. Enumeration of coliforms by membrane filtration is not fully specific. Since the membrane filtration system employed in this study used growth media containing lactose, unusual colonies developed in some specimens. These colonies were dark red, nucleated or without a metallic lustre. Other unusual colours noted were blue, pink, white or colourless colonies lacking sheen. These colonies are not considered as thermal tolerant coliforms by this technique [21].

\section{Results}

\subsection{Physical-Chemical Characteristics and Temporal Trends}

The results of the physical chemical characteristics are shown in the descriptive statistics in Table 2. 
Table 2. Descriptive statistics for the physical chemical properties of various water types.

\begin{tabular}{|c|c|c|c|c|c|c|c|}
\hline \multicolumn{2}{|c|}{ Water type } & $\begin{array}{l}\text { Temp } \\
\left({ }^{\circ} \mathrm{C}\right)\end{array}$ & $\begin{array}{c}E C \\
(\mu \mathrm{S} / \mathrm{cm})\end{array}$ & $\begin{array}{c}D O \\
(\mathrm{mg} / \mathrm{L})\end{array}$ & $\begin{array}{c}P H \\
\text { (pH Units) }\end{array}$ & $\begin{array}{c}\text { Salinity } \\
\text { (PSS) }\end{array}$ & $\begin{array}{c}\text { Turbidity } \\
\text { (NTU) }\end{array}$ \\
\hline \multirow{4}{*}{ Borehole } & Mean & 26.42 & 715.2 & 4.36 & 7.42 & 0.36 & 9.15 \\
\hline & Median & 26.72 & 512.5 & 4.17 & 7.37 & 0.25 & 7.75 \\
\hline & Minimum & 21.06 & 143 & 1.78 & 6.49 & 0.07 & 0.0 \\
\hline & Maximum & 30.75 & 1197 & 8.71 & 8.38 & 0.63 & 66 \\
\hline \multirow{4}{*}{ Lake } & Mean & 25.95 & 156.33 & 3.35 & 7.79 & 0.08 & 82.34 \\
\hline & Median & 26.14 & 140 & 3.36 & 7.88 & 0.07 & 90.25 \\
\hline & Minimum & 23.71 & 125 & 1.03 & 6.33 & 0.06 & 27.9 \\
\hline & Maximum & 29.48 & 331 & 5.25 & 8.79 & 0.16 & 103 \\
\hline \multirow{4}{*}{ River } & Mean & 23.22 & 109.42 & 6.06 & 7.91 & 0.05 & 351.75 \\
\hline & Median & 23.11 & 87.5 & 5.63 & 7.88 & 0.04 & 170 \\
\hline & Minimum & 20.33 & 54 & 1.41 & 7.21 & 0.02 & 25.3 \\
\hline & Maximum & 26.91 & 639 & 10.83 & 8.62 & 0.16 & 2000 \\
\hline \multirow{4}{*}{ Shallow Well } & Mean & 25.8 & 1081.24 & 3.27 & 7.24 & 0.55 & 17.33 \\
\hline & Median & 25.95 & 969 & 2.82 & 7.28 & 0.48 & 11.1 \\
\hline & Minimum & 22.67 & 203 & 0.7 & 5.51 & 0.01 & 1.1 \\
\hline & Maximum & 29.74 & 3510 & 9.05 & 7.89 & 2.01 & 239 \\
\hline \multirow{4}{*}{ Spring } & Mean & 25.2 & 187.54 & 2.43 & 8.27 & 0.11 & 57.18 \\
\hline & Median & 24.78 & 178.5 & 2.05 & 6.55 & 0.1 & 27.75 \\
\hline & Minimum & 23.64 & 0.05 & 0.68 & 5.7 & 0.01 & 6.4 \\
\hline & Maximum & 29.77 & 461 & 5.07 & 41.7 & 0.22 & 456 \\
\hline
\end{tabular}

The water temperature ranges from $21.06^{\circ} \mathrm{C}$ to $30.75^{\circ} \mathrm{C}$. These values are within the $\mathrm{WHO}$ limits of less than $40^{\circ} \mathrm{C}$. The $\mathrm{pH}$ ranges from 5.51 in a shallow well near Lake Victoria to 8.79 for a sample from the Lake. The $\mathrm{pH}$ shows that $80 \%$ of the wells meet WHO standards, while the remaining $20 \%$ are slightly acidic or slightly alkaline. The river water is noted to have the highest mean and maximum concentration of dissolved oxygen in the study area at 10.83 and 1.41 $\mathrm{mg} / \mathrm{l}$ respectively while spring water has the lowest minimum of $0.68 \mathrm{mg} / \mathrm{l}$. Water from shallow wells near Lake Victoria is highly mineralised compared to other water source with electrical conductivity up to $3500 \mu \mathrm{S} / \mathrm{cm}$. Salinity values are generally low apart from water samples from the shallow wells with mean of 0.55 PSS and a maximum of 2.01 PSS. The water temperature does not have direct impacts on human health. However, coliform bacteria survive longer at lower temperatures. The chemical nature of the groundwater will also affect the survival capabilities of any bacteria present. In the unsaturated zone, moisture and temperature are the dominant factors controlling the survival of bacteria in soil, however, reported survival times vary widely and the data are complicated by the possibility of bacterial regrowth [31]. 
Turbidity distribution in Kisumu is highly positively skewed with tail values corresponding to sampling during wet seasons. During the wet season, $90 \%$ of the groundwater sources had turbidity levels higher than 5 NTU, with the highest value of 2000 NTU recorded in R. Kibos during a storm. The lowest turbidity value of 1.1 NTU was recorded during the dry season. Mean turbidity values was 91.7 NTU. Surface water and springs were highly turbid during wet seasons of March and October. In April/May 2018, all the rivers and streams were flooded. Similarly, most of the springs converted into seasonal streams that carried heavy sediment loads. Turbidity of water is caused by the presence of suspended matter or dissolved minerals such as iron. A spring in Kudho has high turdidity throughout the year due to dissolved iron from lateritic soils. Turbidity may indicate pollution from agricultural activities or some disturbance of the underground soil from poorly developed wells. Sediments producing visible turbidity is in most cases composed of fine particles of silt, clay and sand is not detrimental to water quality. The turbidity in water is typically elevated by suspended solids contained in runoff during the wet season and wells that are not properly covered can be particularly susceptible [32]. It was noted during the study that shallow wells' turbidity tended to increase when the water volumes in the wells was low. The high turbidity levels can be attributed to the mud at the bottom of the wells being stirred, increasing turbidity. This may increase the risk of microbial contamination during the dry season. The high levels of turbidity recorded in surface water and springs during heavy rains could be attributed to soil erosion in the hills and increased surface runoff into the springs [33].

\subsection{Statistical Relationships between the Physico-Chemical Parameter in Sampled Kisumu Water}

A negative relationship exists between water conductivity, dissolved oxygen and turbidity, while a strong positive relationship is noted between conductivity and salinity. Dissolved oxygen shows a weak co-relationship with ph. These relationship are shown in the Table 3.

Table 3 aimed at determining the relationship between the physical chemical parameters. There was no overall relationship but electrical conductivity and salinity shown strong correlation.

\subsection{Thermal Tolerant Coliform (TTC) Bacteria and Their Temporal Trends in Kisumu Water}

The bacteriological quality of water in Kisumu is poor, as indicated by high TTC counts. Apart from boreholes, all the other sources of water in Kisumu had growth colonies indicating contamination by faecal coliforms. Out of the 22 water sources sampled, 21 (95.5\%) were contaminated with TTC and only 1 sample conformed to the WHO drinking water standard of 0 TTC per $100 \mathrm{ml}$. The results are shown in Table 4 and in error bars Figure 3.

The high levels of contaminations with thermotolerant bacteria in shallow wells supports the hypothesis that there is a link between the pit latrines and water 
Table 3. Kendall's tau-b non-parametric correlation coefficients of physical chemical parameters.

\begin{tabular}{|c|c|c|c|c|c|c|}
\hline Parameter & $\begin{array}{c}\text { Electrical } \\
\text { Conductivity } \\
(\mu \mathrm{S} / \mathrm{cm})\end{array}$ & $\begin{array}{c}\text { Disolved } \\
\text { Oxygen } \\
(\mathrm{Mg} / \mathrm{L})\end{array}$ & $p H(\mathrm{pH}$ units $)$ & Salinity(PSS) & $\begin{array}{l}\text { Turbidity } \\
\text { (NTU) }\end{array}$ & $\begin{array}{c}\text { Temperature } \\
\left({ }^{\circ} \mathrm{C}\right)\end{array}$ \\
\hline \multicolumn{7}{|l|}{ Electrical } \\
\hline $\begin{array}{l}\text { Conductivity } \\
\qquad(\mu \mathrm{S} / \mathrm{cm})\end{array}$ & 1 & -0.0201 & -0.018 & 0.958 & -0.491 & 0.462 \\
\hline \multicolumn{7}{|l|}{ Dissolved } \\
\hline $\begin{array}{l}\text { Oxygen } \\
(\mathrm{Mg} / \mathrm{L})\end{array}$ & & 1 & 0.377 & -0.206 & 0.148 & -0.0159 \\
\hline $\begin{array}{c}p H \\
\text { (pH units) }\end{array}$ & & & 1 & -0.008 & 0.087 & 0.051 \\
\hline Salinity (PSS) & & & & 1 & -0.00496 & 0.472 \\
\hline $\begin{array}{l}\text { Turbidity } \\
\text { (NTU) }\end{array}$ & & & & & 1 & -0.268 \\
\hline $\begin{array}{c}\text { Temperature } \\
\left({ }^{\circ} \mathrm{C}\right)\end{array}$ & & & & & & 1 \\
\hline
\end{tabular}

Table 4. CFU/100 $\mathrm{ml}$ for the TTC levels in Kisumu during field survey in March, June and December 2017.

\begin{tabular}{ccccc}
\hline Water type & Geometric Mean & Minimum & Maximum & \% of Total N \\
\hline Borehole & 0.00 & 0.0 & 600 & $21.1 \%$ \\
Lake & 78.26 & 32 & 156 & $5.3 \%$ \\
River & 951.59 & 310 & 1400 & $15.8 \%$ \\
Shallow Well & 303.70 & 6 & 1400 & $31.6 \%$ \\
Spring & 124.44 & 13 & 1500 & $26.3 \%$ \\
\hline
\end{tabular}

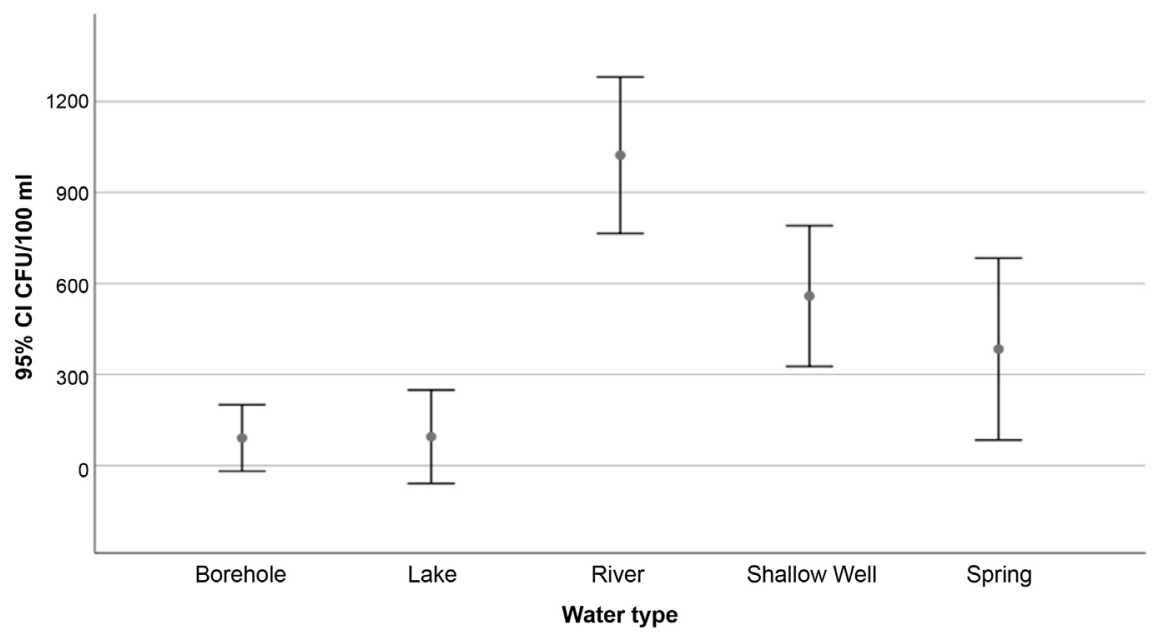

Figure 3. Error bar of TTC at 95\% confidence Interval.

points since the majority of these two sub-surface facilities are located in close to one another. 
All water type in Kisumu are contaminated with TTC and surface water (rivers) has the highest levels of contamination. We attribute this to discharge of raw sewer into the rivers and surface run-off contaminated with faecal matter.

\section{Discussion}

The parallel rise in the use of the sub-surface as a repository of human waste and source of water supply in the informal settlements in Kisumu is of concern from the environmental and health perspectives. The movement of harmful bacteria from the toilets to groundwater make the water unsafe for human consumption and its usage can led to water related diseases. Young children and vulnerable members of the society are therefore at risk.

Detection of thermal tolerant coliform bacteria in the groundwater coupled with the existence pit-latrines in the proximity of water points suggest that the pit latrine influences the bacterial water quality. High usage of pit latrines and shallow wells that lack inner linings and well-head protection correlate well with TTC counts. The unregulated construction of pit-latrines raises concerns that microbial and chemical contaminants discharges from them to groundwater may affect human health.

There is therefore need to study contaminant transport models based on empirical studies that should include pit-latrines and shallow wells siting guidelines. Human excreta are the main input to pit latrines, although other inputs may contribute significantly to pit contents, such as anal cleansing material, menstrual blood and sanitary napkins, and solid refuse, which may contribute significantly to pit contents depending on local practices.

The gradient, location, siting and design of pit latrines and water points can be improved to ensure groundwater and faecal sludge do not mix. We propose regular emptying of the pit latrines whenever economically possible before the hydraulic gradients in the pits is high enough to initiate flows toward the water points or aquifer system. Groundwater contamination is likely in areas where the water table is shallow and in areas where fissured bedrock is over-laid by shallow soils. All efforts should be made to ensure that pit latrines are not located in areas where water table is high, and all cases, digging of deep pit latrines should be discouraged. Deep pit latrines reduces the thickness of the unsaturated zone and this increases the chance of faecal contacts with groundwater. Depending on the type of soil in which the pit latrine is located and the depth to water table, the toilet sludge may migrate into groundwater.

\section{Conclusions}

We concluded that groundwater in Kisumu was contaminated with thermal tolerant bacteria over the study period. The levels of contamination were higher during the rainy seasons for shallow wells, but springs microbial burden decreased during the wet season. It is recommended that shallow wells should be located in areas where they are not likely to be contaminated and they should be 
lined with concrete screens and properly covered. The County Government of Kisumu in consultation with necessary professional should develop guidelines based on the local geology on the separation, direction and maximum depths of pit latrines and well.

Finally, it is recommended that the residents should be informed on the risks posed to their health by digging shallow wells and pit latrine in close proximity. It should be brought to their attention that the sub-surface can be used with caution as a source of groundwater and a repository of human waste. The locals should be advised to use water from the wells with caution to avoid water related diseases more so by the children and the vulnerable in the society. Simple water treatment methods like boiling water before drinking and use of chlorine and other cheap and other readily water treatment chemicals.

\section{Acknowledgements}

This paper is an output from the AfriWatSan project funded by The Royal Society Africa Capacity Building Initiative and the UK Department for International Development (DFID) (Grant Ref. AQ140023). The views expressed and information contained in it are not necessarily those of or endorsed by the Royal Society or DFID, which can accept no responsibility for such views or information or for any reliance placed on them.

\section{Conflicts of Interest}

The authors declare no conflicts of interest regarding the publication of this paper.

\section{References}

[1] UNICEF \& WHO (2017) Launch Version July 12 Main Report: Progress on Drinking Water, Sanitation and Hygiene.

https://www.who.int/mediacentre/news/releases/2017/launch-version-report-jmp-w ater-sanitation-hygiene.pdf

[2] Hopewell, M.R. and Graham, J.P. (2014) Trends in Access to Water Supply and Sanitation in 31 Major Sub-Saharan African Cities: An Analysis of DHS Data from 2000 to 2012. BMC Public Health, 14, 208. https://doi.org/10.1186/1471-2458-14-208

[3] United Nations (2015) The Millennium Development Goals Report. 72 p. https://www.un.org/millenniumgoals/2015_MDG_Report/pdf/MDG\%202015\%20re v\%20(July\%201).pdf

[4] Butterworth, J., Sutton, S. and Mekonta, L. (2013) Self-Supply as a Complementary Water Services Delivery Model in Ethiopia. Water Alternatives, 6, 405-423. https://www.ircwash.org/sites/default/files/self-supply_as_a_complementary_water _services_delivery_model_in_ethiopia.pdf

[5] Ong'Or, B.T.I., and Shu, L.-C. (2007) Water Supply Crisis and Mitigation Options in Kisumu City, Kenya. International Journal of Water Resources Development, 23, 485-500. https://doi.org/10.1080/07900620701488554

[6] Pavelic, P., Giordano, M., Keraita, B., Ramesh, V. and Rao, T. (2012) Ground Water 
Availability and Use in Sub-Saharan Africa: A Review of 15 countries. International Water Management Institute (IWMI), Colombo, Sri Lanka, 274 p. https://doi.org/10.5337/2012.213

[7] Odiyo, J.O. and Makungo, R. (2018) Chemical and Microbial Quality of Groundwater in Siloam Village, Implications to Human Health and Sources of Contamination. International Journal of Environmental Research and Public Health, 15, 317. https://doi.org/10.3390/ijerph15020317

[8] Maoulidi, M. (2010) A Water and Sanitation Needs Assessment for Kisumu City, Kenya. MCI Social Sector Working Paper Series No. 12/2010. http://mci.ei.columbia.edu/files/2014/04/12_Kisumu-WatSan-NA-May2010.pdf

[9] Ritter, L., Solomon, K., Sibley, P., Hall, K., Keen, P., Mattu, G. and Linton, B. (2002) Sources, Pathways, and Relative Risks of Contaminants in Surface Water and Groundwater: A Perspective Prepared for the Walkerton Inquiry. Journal of Toxicology and Environmental Health, 65, 1-142. https://doi.org/10.1080/152873902753338572

[10] Kanyerere, T., Levy, J., Xu, Y. and Saka, J. (2012) Assessment of Microbial Contamination of Groundwater in Upper Limphasa River Catchment, Located in a Rural Area of Northern Malawi. Water $S A, \mathbf{3 8}, 581$.

https://doi.org/10.4314/wsa.v38i4.14

[11] Mbaka, P.K., Mwangi, J.K. and Kiptum, C.K. (2017) Assessment of Water Quality in Selected Shallow Wells of Keiyo Highlands, Kenya. African Journal of Science, Technology, Innovation and Development, 9, 329-338. https://doi.org/10.1080/20421338.2017.1327476

[12] Olajuyigbe, A.E., Olamiju, I.O. and Ola-Omole, C.M. (2017) Vulnerability of HandDug Wells in the Core Area of Akure, Nigeria. Urban Water Journal, 14, 797-803. https://doi.org/10.1080/1573062x.2016.1254257

[13] Tsinda, A., Abbott, P., Chenoweth, J., Pedley, S. and Kwizera, M. (2018) Improving Sanitation in Informal Settlements of East African Cities: Hybrid of Market and State-Led Approaches. International Journal of Water Resources Development, 34, 229-244. https://doi.org/10.1080/07900627.2017.1310090

[14] Lapworth, D., Carter, R.C., Pedley, S. and MacDonald, A.M. (2015) Threats to Groundwater Supplies from Contamination in Sierra Leone, with Special Reference to Ebola Care Facilities.

https://www.researchgate.net/publication/281279344_Threats_to_groundwater_sup plies_from_contamination_in_Sierra_Leone_with_special_reference_to_Ebola_care facilities

[15] Lawrence, A.R., Howard, A.G., Ahmed, K.M. and Nalubega, M. (2001) Guidelines for Assessing the Risk to Groundwater from On-Site Sanitation. British Geological Survey Commissioned Report, CR/01/142. http://nora.nerc.ac.uk/id/eprint/20757/1/ARGOSS\%20Manual.PDF

[16] Kimani-Murage, E.W. and Ngindu, A.M. (2007) Quality of Water the Slum Dwellers Use: The Case of a Kenyan Slum. Journal of Urban Health, 84, 829-838. https://doi.org/10.1007/s11524-007-9199-x

[17] Cave, B. and Kolsky, P. (1999) Groundwater, Latrines and Health. London School of Hygiene \& Tropical Medicine, UK WEDC, Loughborough University, UK. https://www.ircwash.org/sites/default/files/Cave-1999-Groundwater.pdf

[18] WHO (2006) Protecting Groundwater for Health: Managing the Quality of Drinking-Water Sources. IWA Publishing, London. www.who.int/water_sanitation_health/publications/PGWsection1.pdf 
[19] Okotto-Okotto, J., Okotto, L., Price, H., Pedley, S. and Wright, J. (2015) A longitudinal Study of Long-Term Change in Contamination Hazards and Shallow Well Quality in Two Neighbourhoods of Kisumu, Kenya. International Journal of Environmental Research and Public Health, 12, 4275-4291. https://doi.org/10.3390/ijerph120404275

[20] Ayalew, M., Chenoweth, J., Malcolm, R., Mulugetta, Y., Okotto, L.G. and Pedley, S. (2014) Small Independent Water Providers: Their Position in the Regulatory Framework for the Supply of Water in Kenya and Ethiopia. Journal of Environmental Law, 26, 105-128. https://doi.org/10.1093/jel/eqt028

[21] Garcia-Armisen, T., Prats, J. and Servais, P. (2007) Comparison of Culturable Fecal Coliforms and Escherichia Coli Enumeration in Freshwaters. Canadian Journal of Microbiology, 53, 798-801. https://doi.org/10.1139/w07-033

[22] OECD and World Health Organization (2003) Assessing Microbial Safety of Drinking Water Treatment Efficiency; Improving Approaches and Methods, OECD Publishing, Paris, 1-296.

[23] Sclar, G.D., Penakalapati, G., Amato, H.K., Garn, J.V., Alexander, K., Freeman, M. C. and Clasen, T. (2016) Assessing the Impact of Sanitation on Indicators of Fecal Exposure along Principal Transmission Pathways: A Systematic Review. International Journal of Hygiene and Environmental Health, 219, 709-723. https://doi.org/10.1016/j.ijheh.2016.09.021

[24] Hulme, M., Doherty, R., Ngara, T., New, M. and Lister, D. (2001) African Climate Change: 1900-2100. Climate Research, 17, 145-168. https://doi.org/10.3354/cr017145

[25] Herrero, M., Thornton, P.K., Notenbaert, A.M., Wood, S., et al. (2010) Smart Investments in Sustainable Food Production: Revisiting Mixed Crop-Livestock Systems. Science, 327, 822-825. https://doi.org/10.1126/science.1183725

[26] Shackleton, R.M. (1951) A Contribution to the Geology of the Kavirondo Rift Valley. Quarterly Journal of the Geological Society, 107, 336-337. https://doi.org/10.1144/gsl.jgs.1951.107.01-04.15

[27] Striggow, B. (2017) Groundwater Sampling. Operating Procedure, EPA, SESDA, SESDPROC-301-R3.

https://www.epa.gov/sites/production/files/2017-07/documents/groundwater_samp ling301_af.r4.pdf

[28] Graham, N. (1999) Guidelines for Drinking-Water Quality. Addendum to Volume 1-Recommendations, World Health Organisation, Geneva, 184. https://doi.org/10.1016/S1462-0758(00)00006-6

[29] WHO (2017) Guidelines for Drinking-Water Quality. 4th Edition, World Health Organization, Geneva, Licence: CC BY-NC-SA 3.0 IGO. https://apps.who.int/iris/bitstream/10665/254637/1/9789241549950-eng.pdf

[30] Rompré, A., Servais, P., Baudart, J., De-Roubin, M.R. and Laurent, P. (2002) Detection and Enumeration of Coliforms in Drinking Water: Current Methods and Emerging Approaches. Journal of Microbiological Methods, 49, 31-54. https://doi.org/10.1016/s0167-7012(01)00351-7

[31] Sherer, B.M., Miner, J.R., Moore, J.A. and Buckhouse, J.C. (1992) Indicator Bacterial Survival in Stream Sediments. Journal of Environmental Quality, 21, 591-595. http://www.pcwp.tamu.edu/docs/lshs/end-notes/indicatorbacteriased-1261132319/i ndicatorbacteriased.pdf https://doi.org/10.2134/jeq1992.00472425002100040011x

[32] Edokpayi, J., Odiyo, J., Popoola, O. and Msagati, T. (2016) Assessment of Trace 
Metals Contamination of Surface Water and Sediment: A Case Study of Mvudi River, South Africa. Sustainability, 8, 135. https://doi.org/10.3390/su8020135

[33] Wantzen, K. and Mol, J. (2013) Soil Erosion from Agriculture and Mining: A Threat to Tropical Stream Ecosystems. Agriculture, 3, 660-683.

https://doi.org/10.3390/agriculture3040660 